DOI: https://doi.org/10.47405/aswj.v5i1.122

\begin{tabular}{|c|}
\hline Asian Social Work Journal (ASWJ) \\
Volume 5, Issue 1, March 2020 \\
JOURANAL WORK \\
(ASW)
\end{tabular}

\title{
Towards an Inclusive Social Welfare Institution for Disabilities: The Case of Indonesia
}

\author{
Enung Huripah ${ }^{1}$ \\ 1Social Welfare Polytechnic Bandung, Indonesia \\ Correspondence: Enung Huripah (hurip@hotmail.co.id)
}

\begin{abstract}
People with disabilities are vulnerable to experience exclusion and discrimination in society. Likewise in Indonesia, a common condition for people with disabilities is the low level of participation in various sectors, such as the economy, education, healthcare, and public infrastructure. However, Indonesia has committed and started efforts to improve the equality of people with disabilities' access. One institution that plays an important role in this regard is the social welfare institution. On a related note, this study discusses the dynamic of the social welfare institution's roles in Indonesia in providing welfare for people with disabilities. Furthermore, the roles are explored based on the current context of society, which over the last few years, has been changing rapidly due to technological advancements, information acceleration, and big data utilization. This study argues building an inclusive social welfare institution is fundamental to fulfill the people with disabilities' welfare. This study uses a qualitative approach with literature review and secondary data analysis as data collection methods.
\end{abstract}

Key words: disability, inclusive, social welfare institution

\section{Introduction}

The amount of people with disabilities in Indonesia is relatively high. ${ }^{1}$ In 2010 , the World Health Organization (WHO) estimated around $10 \%$ or 24 million people of the Indonesia's population are people with disabilities (WHO, 2011; ILO, 2012). Referring to the 2018 National Socio-Economic Survey (Susenas 2018) by the Statistics Indonesia (BPS) (2019), the amount of people with disabilities in Indonesia that aged over two years reaches $12.29 \%$ or around 31.2 million people. The largest percentage of people with disabilities in Indonesia is in the elderly category by $57.26 \%$, followed by the productive age category by $11.12 \%$ and the children age category (starting at aged two years and above) by $4.19 \%$ (BPS, 2019). Based on its severity, people with disabilities in Indonesia are mostly in the mild disability category by $76.26 \%$, followed by the moderate disability category by $15.07 \%$ and the severe disability category by $8.67 \%$ (BPS, 2019).

\footnotetext{
${ }^{1}$ There are differences regarding the disability surveys results in Indonesia that conducted by several agencies, such as the BPS, the Ministry of Social Affairs (Kemensos), and the Ministry of Health (Kemenkes). Disability surveys by the BPS are showed in reports named Susenas, Census, Supas, and Sakernas; by the Kemensos is showed in SIMPD; and by the Kemenkes is showed in Riskesdas. The differences among them are possible due to dissimilarity in methods and indicators. As for this study refers to the survey that is the most recently released, the Susenas 2018 by the BPS (2019)
} 
People with disabilities in Indonesia have a quite diverse types of disabilities, and so are the causes. The majority of people with disabilities in Indonesia are the people with single disability (has one type of disability) by $54.12 \%$, while the percentage of people with multiple disabilities (has more than one type of disability) is $45.88 \%$ (BPS, 2019). The BPS (2019) showed the most three types of disabilities that people with disabilities in Indonesia's have are difficulty seeing by $60.46 \%$, difficulty walking or climbing stairs by $8.69 \%$, and behavioral and-or emotional disorders by $7.33 \%$. As for other types of disabilities such as difficulty in hearing, using fingers, remembering or concentrating, speaking, and taking care of themselves. The Adioetomo, Mont, and Irwanto's study (2014) found there are several causes regarding disabilities in Indonesia, which the three highest causes are illnesses (such as infections, acute illness, depression, stroke, etc.) by $37.40 \%$, congenital disabilities by $28.15 \%$, and injuries (such as caused by accident, conflict, disaster, poisoning, etc.) by $13.28 \%$.

The main issue for people with disabilities is the vulnerability of experiencing exclusion and discrimination in society (UNCRPD, 2006; UNDP, 2018), so this is the issue that needs to be overcome in order to provide welfare for them. Relatedly, Indonesia had participated in ratifying the Convention on the Rights of Persons with Disabilities (CRPD) by the United Nations (UN) in 2011. This clearly indicates that Indonesia has committed, following other countries that have ratified the CRPD first, in recognizing the people with disabilities' rights based on human rights and social approaches (Monash University, 2017; SMERU, 2019). Following this step, Indonesia had passed the 8/2016 Law and the 52/2019 Government Regulation on disability (Monash University, 2017; SMERU, 2019). Through these two legal protections, providing people with disabilities' welfare in Indonesia has been more institutionalized with clear directions.

One of Indonesia's institutions that plays an important role in providing welfare for people with disabilities is the social welfare institution. The "social welfare institution" term refers to a series of institutionalized activities (regulation, planning, implementation, monitoring, and evaluation) in providing social services (DuBois \& Milley, 2005; Suharto, 2009), such as social rehabilitation, social security, social protection, and social empowerment. This involves a number of actors like the government, ministries - especially the Ministry of Social Affairs (Kemensos), local bureausespecially the social bureaus (Dinsos), non-governmental organizations (NGOs), social centers, social workers and volunteers, or private organizations. Targets or beneficiaries of these social services are vulnerable people, for example poor people, homeless, street children, the elderly, and others including people with disabilities.

Hence, this study discusses the dynamic of the social welfare institution's roles in Indonesia in providing welfare for people with disabilities. This study argues building an inclusive social welfare institution is fundamental to fulfill the people with disabilities' welfare. For this study, referring to the studies or research reports by Rimmerman (2013), Carter (2014), Rohwerder (2015), and DFID (2018), "an inclusive social welfare institution" in this context means the institutionalized social services for people with disabilities based on four principles, namely human rights, full accessibility, active participation, and data-based approach.

There are quite a lot of studies in Indonesia discussing issues related to social welfare institution and disability. However, so far, these studies tend to discuss the planning, implementation, monitoring, and evaluation of social services for disabilities, such as the studies by Irwanto, Christiane, and Natalia (2010), Hikmawati and Rusmiyati (2011), Hidayatullah and Prawono (2018), Salsabila, Krisnani, and Apsari (2018), and Syobah (2018). Therefore, this study is relatively different because it addresses the issue in institutionalized context through developing inclusive scheme in social services. Moreover, this study also explores the issue based on the current context of society, which over the last few years, has been changing rapidly due to technological advancements, information acceleration, and big data utilization. 
DOI: https://doi.org/10.47405/aswj.v5i1.122

\section{Methodology}

This study uses a qualitative approach with indirect data collection method. That is, referring to Onwuegbuzie \& Frels (2016), this study does not collect data by in-depth interviews or field observations, rather utilizes a comprehensive literature review (CRL) method. According to Onwuegbuzie \& Frels (2016), CRL is an approach or procedure for obtaining information through data sources like study results, research reports, or other data-based writings. This is a valid form of method due to its own potential, namely a coherent foundation in the strict investigation of logical relations between justification, argumentation, procedure, and rationality (Onwuegbuzie \& Frels, 2016). CRL is possible to be used if the study's position is a critical or dialectical study (Onwuegbuzie \& Frels, 2016) - this condition is in line with this study's purpose context, which is to make a dialectical study, specifically by developing inclusive scheme in social services for the people with disabilities' welfare.

As for this study conducts literature review and secondary data analysis for data collection methods. Literature review means the information that is obtained sourced from journal articles, research reports, and scientific books, while secondary data analysis sourced from a survey report that conducted by an authorized agency. This study applies seven stages in CRL in order to be completed, namely exploring topic, initiating the search of information from data sources (in this study, data sources such as literature review and secondary data analysis), storing and organizing information, selecting or deselecting information, expanding the search of information for analytical preparation, analyzing and synthesizing information, and presenting the information in an organized study or report (Onwuegbuzie \& Frels, 2016).

\section{People with Disabilities' Vulnerability}

As it has mentioned earlier, people with disabilities are vulnerable to experience exclusion and discrimination. Exclusion is a marginalized process of individual groups from societal activities (Bowring, 2000; Davies, 2005; Allman, 2013). Furthermore, these groups of individuals are at a disadvantage situation due to minority aspects they have, such as ethnicity, race, religion, sexual orientation, caste, gender, age, status, etc. including disability, thus they are systematically discriminated (Beall \& Piron, 2005). Exclusion as a concept has multidimensional and dynamic natures, so these cause exclusion to occur in both micro and macro levels of social life (Maldonado, Pogrebnyakov, \& Gorp, 2006). The notion of exclusion indicates there are complex social phenomena concerning the group of individuals' powerlessness (Bowring, 2000; Davies, 2005; Tobias \& Mukhopadhyay, 2017).

Specifically, regarding exclusion and discrimination of people with disabilities, they often encounter structural and social barriers in accessing development (Tobias \& Mukhopadhyay, 2017); even though now, on a global scale, the amount of people with disabilities tends to increase due to various reasons, such as an increase in the elderly population, health matters, or injuries (Boyle et al., 2011; McNally \& Frueh, 2013; Freedman, 2015). There have been many studies and research reports in the global context that prove people with disabilities experience exclusion and discrimination in the development process. These studies and research reports show people with disabilities are not getting access to the jobs, education, healthcare, housing, public infrastructure, information and communication technology, as well as community or social activities (Loeb \& Eide, 2004; Hall, 2005; Ren, Paetzold, \& Colella, 2008; Groce et al., 2011; WHO, 2011; Mitra, 2014; UNDP, 2018). As a result, people with disabilities seem to live in a limited life, they get minimal access to enjoy a valueable life. Exclusion and discrimination are certainly painful experiences for people with disabilities (Kitchin, 1998). Both of these, in fact, are determinants that worsen the people with disabilities' psychosocial condition, whether in the short or long term (Eisenberger \& Lieberman, 2004; Tobias \& Mukhopadhyay, 2017).

In the context of Indonesia, several research reports also have addressed the issue above. The SMERU report (2019), for instance, stated people with disabilities in Indonesia tend to be less prosperous in the economic aspects than non-disabilities. In 2018 , the ratio of the poverty rate between people with disabilities to non-disabilities is $11.04 \%$ to $9.49 \%$. Then, the ratio of the labor participation between 
DOI: https://doi.org/10.47405/aswj.v5i1.122

people with disabilities to non-disabilities is $55 \%$ to $70 \%$. Another report by the UN (2019) said Indonesia is one of the countries with the greatest education gap for people with disabilities and nondisabilities. The ratio of the school participation at 15 to 29 years old between people with disabilities to non-disabilities is $53 \%$ to $98 \%$. Lastly, the Monash University report (2017) wrote the majority of people with disabilities in Indonesia are still excluded in the health sector. People with disabilities who report needing assistive aids turned out do not get it, with the details of $80 \%$ do not getting sighting aids, $28 \%$ do not getting walking aids, and $91 \%$ do not getting hearing aids. Unfortunately, these things can lead to people with disabilities have a low level of awareness and confidence (Kitchin, 1998).

\section{The Inclusive Institution for People with Disabilities}

In order to overcome the people with disabilities' vulnerability problem, an inclusive approach has been believed to be the best way over the last few years. This has been conveyed by a number of studies and research reports, which some advantages like expanding other benefits in the society because it opens up an opportunity for other minorities' participation, improving individuals' and families' well-being, increasing labor market productivity, taxes, and the economy as a whole, and this is also more cost effective than a piecemeal approach per sector (WHO \& World Bank, 2011; Heymann, Stein, \& Moreno, 2014; Lamicchane, 2015; Rohwerder, 2015; UNDP, 2018). However, in this way, the important note is there must be systematic and comprehensive changes, not just in the micro level through shifting individual behavior. The institutional change is needed in development or humanism project that promotes people with disabilities inclusiveness (Coe \& Wapling, 2010; Bruijn et al., 2012; Wapling \& Downie, 2012).

The key to an inclusive approach indeed lies in institutional change. There are several evidences that explain inequality and social disintegration as a result of the growth of some kind barrier, not about self-limitation (Groce et al., 2011; Groce \& Bakhsi, 2011; WHO \& World Bank, 2011; Bruijn et al., 2012; Groce \& Kett, 2014; Heymann, Stein, \& Moreno, 2014; Rohwerder, 2015). It means, in this context, the unequal opportunities between people with disabilities and non-disabilities are a structural product, not due to differences between the two. This is the reason people with disabilities are vulnerable and they are not getting access to the jobs, education, healthcare, housing, public infrastructure, information and communication technology, as well as community or social activitiesas it has discussed in the previous section.

Therefore, the inclusive institution should be systematically applied and practiced in a sustainable manner. Inclusive institution as a concept has certainly a multidimensional nature and a variety of principles-due to its systematic and comprehensive scopes (Rimmerman, 2013; Carter, 2014). Specifically in the context of people with disabilities, there are a number of studies and research reports that have discussed it. These studies and research reports can be mapped in different dimensions, such as the inclusive institution that emphasizes on mainstreaming (Coe \& Wapling, 2010; Bruijn et al., 2012), twin track approach (Ju'beh, 2015), raising awareness and changing behavior (Coe, 2012), universal design (WHO \& World Bank, 2011), reasonable accomodation (Leymat, 2012; Fanu, 2015), participation (Smith, Jolley, \& Schmidt, 2012), rights-based initiatives (Wapling \& Downie, 2012), community-based rehabilitation (Biggeri et al., 2014; Mauro et al., 2014), livelihood approach (Mitra, 2014; Mont, 2014), and building back better (Mitchell \& Karr, 2014). However, from all of that, essentially, the inclusive institution is an equal recognition of rights, entitlements, opportunities, and voices for vulnerable people in the allocation of institutionalized resources and services (Rimmerman, 2013; Carter, 2014; Rohwerder, 2015 ; DFID, 2018).

At the practical level, the global spirit in implementing inclusive institution for people with disabilities is illustrated through the CRPD commitment in 2006. This is a kind of guide to promote, protect, and ensure people with disabilities to enjoy human rights and fundamental freedoms fully and equally, as well as their dignity is respected (UNCRPD, 2006; UNDP, 2018). The CRPD marked a shift in the institutional model approach for people with disabilities. Before this, the institutional model for people with disabilities was medical (focused on healing people with disabilities) and charity approaches (focused on giving donations to people with disabilities, not about empowerment) (UNCRPD, 2006; 
UNDP, 2018). However, on the after, the model shifted to human rights and social approaches, thereby the importance of inclusive schemes for people with disabilities is more recognized (UNCRPD, 2006; UNDP, 2018). This was an important starting point for countries to adopt the inclusive institution for people with disabilities. Moreover, the model has also been included in the 2008 International Law (Mji et al., 2009) and as an important agenda in the 2030 Sustainable Development Goals (SDGs) Indonesia has also committed to achieve it (Monash University, 2017; SMERU, 2019).

\section{The Social Welfare Institution's Roles for People with Disabilities in the Institutional Context of Indonesia}

One of institutions that has roles in the inclusive institution mechanism for people with disabilities in Indonesia is the social welfare institution. After Indonesia have ratified the CRPD global commitment in 2011, by issuing the 19/2011 Law about the Ratification of the Convention on the Rights of People with Disabilities, Indonesia changed the 4/1997 Law about People with Disabilities into the 8/2016 Law (Monash University, 2017; SMERU, 2019). This indicated that Indonesia was no longer using a medical approach on disability issues, rather shifting to human rights and social approaches (Monash University, 2017; SMERU, 2019). That is, in order to overcome the people with disabilities' problem, Indonesia would work within the framework of "the importance of developing a social environment that is able to accommodate the people with disabilities' participation and the empowerment of them". For this reason, one of the efforts made by Indonesia was issuing the 52/2019 Government Regulation about the Implementation of Social Welfare for People with Disabilities - as a practical regulation of the $8 / 2016$ Law. Based on this government regulation, the social welfare institution is responsible in providing welfare for people with disabilities.

Specifically, referring to the 52/2019 Government Regulation, the social welfare institution in Indonesia should provides welfare for people with disabilities through four forms of social services. Indeed, this is in line with the concept, the "social welfare institution" term refers to a series of institutionalized activities (regulation, planning, implementation, monitoring, and evaluation) in providing social services (DuBois \& Milley, 2005; Suharto, 2009). The purpose of these social services is to provide the people with disabilities' basic needs, ensure the social functionality of people with disabilities, improve people with disabilities' social welfare with dignity, and realize an inclusive society as a whole. Here are the four forms of social services that are meant above:

a. Social rehabilitation: the processes of re-functionalization and development that enable people with disabilities to be able to carry out their social functions properly in the societal life

b. Social security: an institutionalized scheme to ensure all people with disabilities can properly fulfill their basic needs

c. Social protection: efforts that directed people with disabilities to be able to prevent and deal with social risk, thus their survival can be met according to minimum basic needs

d. Social Empowerment: efforts to strengthen the people with disabilities' ability like potential development and also improvement of access, thus they are able to grow and develop into strong and independent individuals or groups

The actors who are involved, as parts of social welfare institution, to provide social services for people with disabilities are clearly diverse. Central and local government agencies (including ministries, bureaus, and local bureaus) would act as leading institutions (SMERU, 2019). Their role is the party who is obliged to make regulation and perform planning, implementation, monitoring, and evaluation of social services in order to provide welfare for people with disabilities. Then, there are others such as the organizations of people with disabilities (OPDs), NGOs, social centers, social workers and volunteers, or private organizations that act as supporting institutions (SMERU, 2019). Their role is to assist in planning, implementation, monitoring, and evaluation of social services. In order to ensure the synchronization of policies, programs, and budgets across sectors in this regard, the primary responsibility lies with the Ministry of Social Affairs-with the social bureaus helping at the regional level (SMERU, 2019). The target or beneficiary of social services is not only people with disabilities as individuals and groups or communities, but also their families. 
DOI: https://doi.org/10.47405/aswj.v5i1.122

As for budget allocation of social services for people with disabilities comes from three things. The sources are the State Revenue and Expenditure Budget (APBN), the Regional Revenue and Expenditure Budget (APBD), and other legitimate sources according to regulations - such as donations or the results of cooperation with companies like corporate social responsibility (CSR) programs. In general, referring to the SMERU report (2019), the budget allocation for activities related to people with disabilities in 2017 is IDR 309 billion. The majority of these budgets are distributed in the Ministry of Social Affairs, the Coordinating Ministry for Human Development and Culture (Kemenko PMK), and the Coordinating Ministry for Politics, Law, and Security (Kemenko Polhukam). The budget allocations distribution is uneven because around $90 \%$ are in the Ministry of Social Affairs.

\section{Enhancing the Inclusive Social Welfare Institution for People with Disabilities in Indonesia}

There are several challenges for the social welfare institution in providing welfare for people with disabilities in Indonesia through social services. These challenges impede the fulfillment of "social welfare" and "accessibility" meanings for people with disabilities - as mandated in 52/2019 Government Regulation. According to this government regulation, "social welfare" is the condition of people with disabilities' needs like material, spiritual, and social are fulfilled in order to be able to live properly and develop themselves, thus they can carry out their social functions; then, "accessibility" is the convenience that is provided for people with disabilities to realize equal opportunity. Compiled based on the studies or research reports by Irwanto, Christiane, and Natalia (2010), Hikmawati and Rusmiyati (2011), Adioetomo, Mont, \& Irwanto (2014), Monash University (2017), Hidayatullah and Prawono (2018), Salsabila, Krisnani, and Apsari (2018), Syobah (2018), and SMERU (2019), here are the main challenges that are meant above:

a. There are still a lot of bad stigma against people with disabilities in society, thus it impedes the fulfillment of social rehabilitation and empowerment purposes

b. Lack of resources to increase coverage and adequacy of social security and protection for people with disabilities

c. The complexity to manage stakeholders with different interests concerning the social rehabilitation and empowerment impacts for people with disabilities

d. Lack of assistive technology for people with disabilities in social centers

All these challenges signify the importance of strengthening the inclusive social welfare institution for people with disabilities in Indonesia. That is, this is must to be an institutional improvement, or improvement that carried out systematically, in the matter of providing social services based on an inclusive approach. Seeing the challenges above, and by referring to the studies or research reports by Rimmerman (2013), Carter (2014), Rohwerder (2015), and DFID (2018), this study proposes the social welfare institution in Indonesia should emphasize four principles, namely human rights, full accessibility, active participation, and data-based approach. Here are the elaboration of these four:

a. Human Rights

This principle means the importance of recognizing and respecting people with disabilities' rights and entitlements in social services. This principle is essential in order to overcome the challenge number one above, namely regarding bad stigma against people with disabilities in society. As a result, with the bad stigma decrease, there will be many parties who will help in social services implementation, such as increasing social volunteers or corporate assistance through CSR programs. Here are examples of activities in implementing this principle:

- Collaborate with OPDs and communities in carrying out a massive and structured advocacy or public campaign regarding "people with disabilities' rights and entitlements" or "the inclusiveness of people with disabilities" in order to increase public awareness of people with disabilities

- Collaborate with the educational institution in providing teaching materials regarding "people with disabilities' rights and entitlements" or "the inclusiveness of people with disabilities" 
DOI: https://doi.org/10.47405/aswj.v5i1.122

- Develop and publicize disability-friendly pilot areas (either city or village). This is also useful to increase public awareness of people with disabilities

b. Full Accessibility

This principle means the importance of equal access and impact of social services for people with disabilities. This principle is essential in order to overcome the challenge number two above, namely regarding lack of resources in social services. Here are examples of activities in implementing this principle:

- Maximizing the external funding system such as donations from international organizations or companies through CSR programs

- Collaborate with start-ups to develop supporting technology application that is able to increase coverage of social security and protection for people with disabilities

- Synchronization of central and regional policies concerning disability issues. This is due to only around 6 provinces and 20 districts/cities that have implemented an institutional model based on new approaches (human rights and social) that refer to 8/2016 Law (SMERU, 2019). This is also fundamental in order to realize a better and equal impact of social services for people with disabilities

c. Active Participation

This principle means society should aware that people with disabilities is not an object, rather subject. Therefore, people with disabilities need to have an equal voice and empowerment in social services. This principle is essential in order to overcome the challenge number three above, namely regarding manage stakeholders with different interests concerning the social services impacts. Here are examples of activities in implementing this principle:

- Hastened the establishment of National Disability Commission (KND) (SMERU, 2019). Indeed, at the regulatory level, Indonesia has a relatively comprehensive law on disability issues based on human rights and social approaches. However, Indonesia is still weak in the monitoring and evaluating social rehabilitation and-or empowerment impacts for people with disabilities in integrated manner. Thus, the presence of KND should be able to overcome this issue, as the KND is a party with strategic roles of "developing master plan of the social rehabilitation and-or empowerment impacts for people with disabilities" and "synchronizing monitoring and evaluation aspects of the social rehabilitation and-or empowerment impacts for people with disabilities"

- Improving the empowerment and independence of OPDs or communities in order to be able to be fully involved in the planning, monitoring, and evaluation of social services for people with disabilities. This is fundamental as an effort to provide an equal voice for people with disabilities. As a result, the social services will be better because the programs accommodate what people with disabilities actually needs

- Collaborate with start-ups to develop technology application about "the labor market information for people with disabilities" or "a marketplace specifically for products from entrepreneur with disabilities"

d. Data-based approach

This principle means social services for people with disabilities should be implement with an integrated database. This principle is essential in order to overcome all of the challenges above. Implementing this principle in a suitable manner is a key to apply the three preceding principles successfully. This also should be maximized because it follows the current context of society, which over the last few years, has been changing rapidly due to technological advancements, information acceleration, and big data utilization. Here are examples of activities in implementing this principle:

- Integrate and utilize research and surveys results on people with disabilities for the better social services. So far, Indonesia has been considered weak concerning the integration and also publication of research and surveys results on people with disabilities (Monash University, 2017; Kompas, 2019; SMERU, 2019). Whereas, studies have emphasized the lack of attention to the statistics utilization, the lack of research and surveys funds, and the lack of integration and transparency of research and surveys results related to disability issues can caused on poor performance in 
DOI: https://doi.org/10.47405/aswj.v5i1.122

the inclusiveness of planning and evaluating social services for people with disabilities (Groce et al., 2011; Rohwerder, 2015). Therefore, the social welfare institution in Indonesia must immediately focus on this matter, namely social services for people with disabilities should be implement with an integrated and transpatent database

- Collaborate with start-ups to develop and innovate on assistive technology for people with disabilities

Picture 1 Enhancing the Inclusive Social Welfare Institution for People with Disabilities in Indonesia Scheme

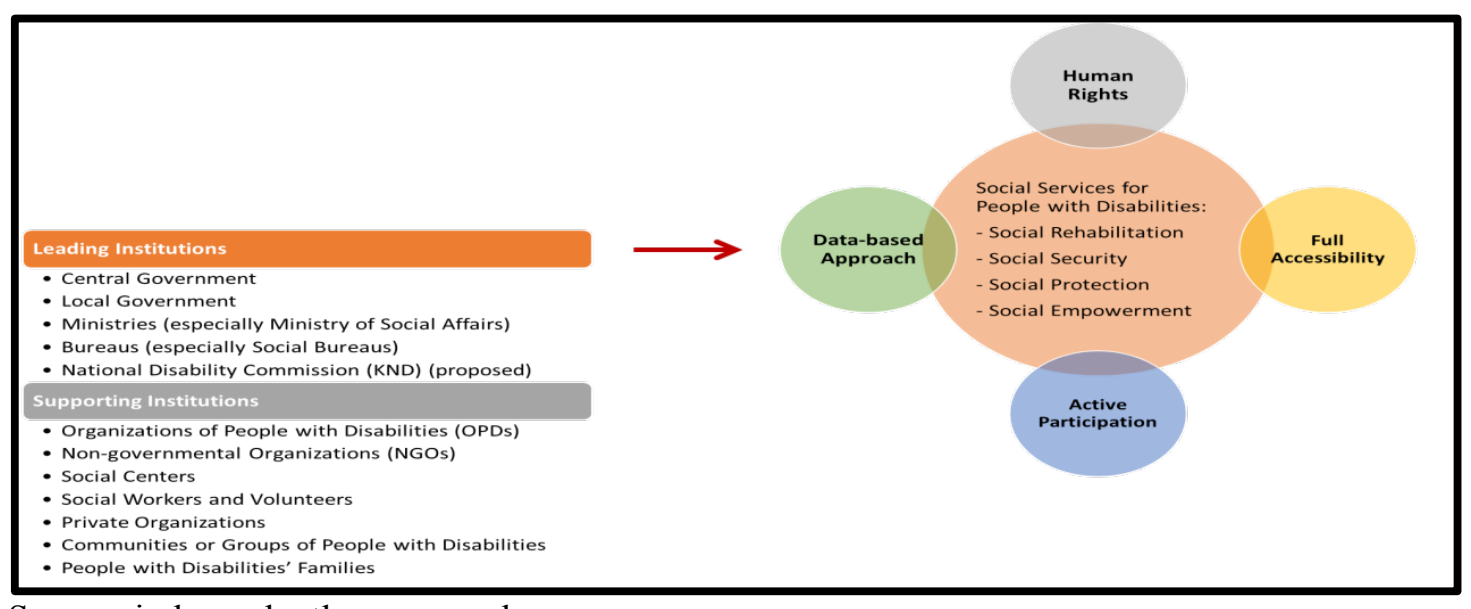

Source: independently processed

\section{Conclusion}

This study emphasizes the importance of strengthening the inclusive social welfare institution for people with disabilities in Indonesia. This means, for this study, there needs to be an institutional improvement in the matter of providing social services (social rehabilitation, social security, social protection, and social empowerment) based on four inclusive principles, namely human rights, full accessibility, active participation, and data-based approach. Implementing the last principle in a suitable manner is a key to apply the three preceding principles successfully. Especially in the context of Indonesia, that has been considered weak concerning the integration and also publication of research and surveys results on people with disabilities. Whereas, this can caused on poor performance in the inclusiveness of planning and evaluating social services for people with disabilities. Therefore, the social welfare institution in Indonesia must immediately focus on this matter, namely social services for people with disabilities should be implement with an integrated and transpatent database.

\section{References}

Adioetomo, S. M., Mont, D., \& Irwanto. (2014). Persons with Disabilities in Indonesia (Empirical Facts and Implications for Social Protection Policies). Jakarta: Tim Nasional Percepatan Penanggulangan Kemiskinan.

Allman, D. (2013). The Sociology of Social Inclusion. SAGE Open January-March 2013, 1-16.

Beall, J., \& Piron, L.-H. (2005). DFID Social Exclusion Review. London: London School of Economics and Political Science.

Biggeri et al. (2014). Do Community-based Rehabilitation Programmes Promote the Participation of Disabilities? A Case Control Study from Mandya District, in India . Disability \& Rehabilitation, Vol. 36, No. 18, 1508-1517.

Bowring, F. (2000). Social Exclusion: Limitations of the Debate. Critical Social Policy, Vol. 20, 307330. 
DOI: https://doi.org/10.47405/aswj.v5i1.122

Boyle et al. (2011). Trends in the Prevalance of Developmental Disabilities in US Children 19972008. Pediatrics, Vol. 127, No. 6, 1034-1042.

BPS. (2019). Survei Sosial-Ekonomi Nasional 2018. Jakarta: Badan Pusat Statistik.

Bruijn et al. (2012). Count Me In: Include People with Disabilities in Development Projects (A Practical Guide for Organization in North and South). Veenedaal: Light for the World.

Carter, B. (2014). Inclusive Institution: Topic Guide. Birmingham: GSDRC, University of Birmingham.

Coe, S. (2012). More Practical Lessons from Five Projects on Disability-Inclusive Development . Development in Practice, Vol. 22, No. 3, 400-408.

Coe, S., \& Wapling, L. (2010). Practical Lessons from Four Projects on Disability-Inclusive Development Programming. Development in Practice, Vol. 20, No. 7, 879-886.

Davies, J. S. (2005). The Social Exclusion Debate: Strategies, Controversies, and Dilemmas. Policy Studies, Vol. 26, 3-27.

DFID. (2018). DFID's Strategy for Disability Inclusive Development 2018-2023. London: Department for International Development, UK Government.

DuBois, B., \& Milley, K. K. (2005). Social Work: An Empowering Profession. Boston: Pearson.

Eisenberger, I. N., \& Lieberman, D. M. (2004). Why Rejection Hurts: The Neurocognitive Overlap between Physical and Social Pain. Trends in Cognitive Sciences, Vol. 8, 294-300.

Fanu, G. L. (2015). Imagining Disability? Conceptualizations of Learners with Disabilities and Their Learning in the Pedagogic Manuals of International Development Agencies. International Journal of Educational Development, Vol. 40, 267-275.

Freedman, J. (2015). Gendering the International Asylum and Refugee Debate. London: Palgrave Macmillan.

Groce et al. (2011). Disability and Poverty: The Need for a More Nuanced Understanding of Implications for Development Policy and Practice . Third World Quarterly, Vol. 32, No. 8, 1493-1513.

Groce, N. E., \& Bakhsi, P. (2011). Illiteracy Among Adults with Disabilities in the Developing World: A Review of the Literature and a Call for Action. International Journal of Inclusive Education, Vol. 15, No. 10, 1153-1168.

Groce, N. E., \& Kett, M. (2014). Youth with Disabilities (Working Paper Series: No. 23). London: Leonard Cheshire Disability and Inclusive Development Center.

Hall, E. (2005). The Entangled Geographies of Social Exclusion/Inclusion for Disabilities. International Journal of Special Education, Vol. 25, No. 3, 107-115.

Heymann, J., Stein, M. A., \& Moreno, G. (2014). Disability and Equality at Work. New York: Oxford University Press.

Hidayatullah, A. N., \& Pranowo. (2018). Membuka Ruang Asa dan Kesejahteraan bagi Penyandang Disabilitas. Jurnal PKS, Vol. 17, No. 2, 195-206.

Hikmawati, E., \& Rusmiyati, C. (2011). Kebutuhan Pelayanan Sosial Penyandang Cacat. Informasi, Vol. 16, No. 01, 17-32.

ILO. (2012). Inklusi Penyandang Disabilitas di Indonesia. Jakarta: International Labour Organization.

Irwanto, Christiane, N., \& Natalia, S. (2010). Evaluasi Program Bantuan Sosial bagi Penyandang Cacat (Internal Report to Bappenas). Jakarta: Badan Perencanaan Pembangunan Nasional.

Ju'beh, K. A. (2015). Disability Inclusive Development Toolkit. CBM: Bensheim.

Kitchin, R. (1998). "Out of Place", "Knowing One's Place": Space, Power, and the Exclusion of Disabled People. Disability \& Society, Vol. 13, 343-356.

Kompas. (2019, Desember 17). Data Disabilitas yang Membingungkan. Retrieved Januari 23, 2020, from Kompas: https://bebas.kompas.id/baca/riset/2019/12/17/data-disabilitas-yangmembingungkan/

Lamicchane, K. (2015). Disability, Education, and Employment in Developing Countries: From Charity to Investment. Cambridge: Cambridge University Press.

Leymat, A. (2012). Inclusive Microfinance: Reaching Disabled People through Partnership Development. Enterprise Development and Microfinance, Vol. 23, No. 1, 25-37.

Loeb, M., \& Eide, A. (2004). Living Conditions Among People with Activity Limitations in Malawi: A National Representative Study. Oslo: SINTEF Health Research.

Maldonado, E. A., Pogrebnyakov, N. A., \& Gorp, A. F. (2006). ICT Policies as a Means to Inhibit Social Exclusion: The South African Case. In e. a. Trauth, Social Inclusion: Societal and 
DOI: https://doi.org/10.47405/aswj.v5i1.122

Organizational Implications for Information Systems (pp. 137-150). New York: Springer Publishing.

Mauro et al. (2014). The Effectiveness of Community-based Rehabilitaion Programs: An Impact Evaluation of Quasi-randomised Trial . Journal of Epidemology \& Community Health, Vol. 68, 1102-1108.

McNally, R. J., \& Frueh, B. C. (2013). Why Are Iraq and Afghanistan War Veterans Seeking PTSD Disability Compensation at Unprecedented Rates? Journal of Anxiety Disorders, Vol. 27, No. 5, 520-526.

Mitchell, D., \& Kerr, V. (2014). Crises, Conflict, and Disability: Ensuring Equality. New York: Routledge.

Mitra, S. (2014). Employment Challenges and Successes in Low- and Middle-Income Countries. In J. Heymann, M. Stein, \& G. Moreno, Disability and Equality at Work. New York: Oxford University Press.

Mji et al. (2009). Networking in Disability for Development: Introducing the African Network for Ecidence-to-Action on Disability (AfriNEAD). In M. MacLachlan, \& L. Swartz, Disability \& International Development: Towards Inclusive Global Health. New York: Springer Publishing.

Monash University. (2017). Disability in Indonesia: What Can We Learn from the Data? Jakarta: Australia Indonesia Partnership for Economic Governance (AIPEG).

Mont, D. (2014). Employment Policy Approaches and Multisectoral Implementation in Low- and Middle-income Countries. In J. Heymann, M. Stein, \& G. Moreno, Disability and Equality at Work. New York: Oxford University Press.

Onwuegbuzie, A. J., \& Frels, R. (2016). 7 Steps to a Comprehensive Literature Review (A Multimodal $\&$ Cultural Approach). London: Sage Publications.

Ren, L. R., Paetzold, L. R., \& Colella, A. (2008). A Meta-analysis of Experimental Studies on the Effects of Disability on Human Resource Judgments. Human Resource Management Review, Vol. 18, No. 3, 191-203.

Rimmerman, A. (2013). Social Inclusion of People with Disabilities: National and International Perspectives. Cambridge: Cambridge University Press.

Rohwerder, B. (2015). Disability Inclusion: Topic Guide. Birmingham: GSDRC, University of Birmingham.

Salsabila, N., Krisnani, H., \& Apsari, N. C. (2018). Rehabilitasi Sosial bagi Remaja dengan Disabilitas Sensorik. Jurnal Pekerjaan Sosial, Vol. 1, No. 3, 190-203.

SMERU. (2019). Kendala Mewujudkan Pembangunan Inklusif terhadap Penyandang Disabilitas. Jakarta: The SMERU Research Institute.

Smith, F., Jolley, E., \& Schmidt, E. (2012). Disability and Disasters: The Importance of an Inclusive Approach to Vulnerability and Social Capital. Stockholm: The World We Want Foundation.

Suharto, E. (2009). Development of Social Welfare in Indonesia: Situation Analysis and General Issues. International Conference on Building Capacity and Policy Netwroking for Effective Welfare Development (pp. 1-8). Jakarta: Center for International Administration Studies, National Institute of Public Administration.

Syobah, S. N. (2018). Pemberdayaan Penyandang Disabilitas di Provinsi Kalimantan Timur. Nuansa, Vol. 15, No. 2, 252-272.

Tobias, E. I., \& Mukhopadhyay, S. (2017). Disability and Social Exclusion: Experiences of Individuals with Visual Impairments in the Oshikoto and Oshana Regions of Namibia. Psychology and Developing Societies, Vol. 29, No. 1, 22-43.

UN. (2019). Disability and Development Report 2018 (Realizing the Sustainable Development Goals by, for and with Persons with Disabilities). New York: Department of Economic and Social Affairs of United Nations.

UNCRPD. (2006). Convention on the Rights of Persons with Disabilities and Optional Protocol. United Nations Convention on the Rights of Persons with Disabilities: New York.

UNDP. (2018). Disability Inclusive Development in UNDP (Guidance and Entry Points). New York: United Nations Development Programme.

Wapling, L., \& Downie, B. (2012). Beyond Charity: A Donor's Guide to Inclusion (Disability Funding in the Era of the UN Convention on the Rights of Persons with Disabilities. Boston: Disability Rights Fund.

WHO \& World Bank. (2011). World Report on Disability. Geneva: World Health Organization. 
Asian Social Work Journal (ASWJ), Volume 5, Issue 1, (page 18 - 28), 2020

DOI: https://doi.org/10.47405/aswj.v5i1.122

WHO. (2011). World Disability Report and Rehabilitation. Geneva: World Health Organization. 